\title{
Determinants of Russia's Sovereign Risk
}

\author{
Evgenia Grigoryeva, Bank of Russia ${ }^{1}$ \\ eivolkova3@gmail.com
}

This paper presents an empirical analysis of the determinants of Russia's sovereign risk. The spreads on sovereign Russian credit default swaps (CDS) were used as a measure of risk. Based on the accuracy of out-of-sample forecasts, the factors that influence Russian CDS were selected: the implied volatility of the rouble exchange rate, the size of foreign exchange reserves relative to GDP, and the average spread on other emerging market CDS as a proxy for global factors. In turn, the CDS of emerging market economies are determined by the volatility of their currencies, the slope of the US government bond yield curve, and also by the increments of the dollar index.

Keywords: sovereign risk, CDS, Russia, emerging market economies

JEL Codes: C32, G15, F34
Citation: Grigoryeva, E. (2021).

Determinants of Russia's Sovereign Risk. Russian Journal of Money and Finance, 80(4), pp. 74-97.

doi: $10.31477 /$ rjmf.202104.74

\section{Introduction}

A country's ability to meet its debt obligations on time is an important factor on which both the financial and real sectors of its economy depend. If investors have doubts about the solvency of the state, the funding cost for the state increases due to the higher risk compensation, which is reflected in the cost of borrowing for the private sector, and also leads to an increase in the overall level of interest rates in the economy, a fall in the value of equities, and a weakening of the national currency. As a result, tightening monetary conditions and falling exchange rates affect inflation and real output (Augustin et al., 2018; Bocola, 2016; Breckenfelder, 2018; Della Corte et al., 2021; Panetta et al., 2011; Reinhart and Rogoff, 2008). Thus, in Russia in 1998, falling oil prices in the context of a persistent budget deficit and rising external debt, as well as the unfolding Asian crisis, made investors reconsider the soundness of Russian debt investments, which led to significant capital outflows, a collapse of the rouble exchange rate, an increase in government bond yields up to $50 \%$, an increase in inflation of more than 70 percentage points, and a fall in GDP by $5.3 \%$ (Kose et al., 2021). During the European debt crisis, sovereign bond yields increased significantly in Greece, Ireland, Portugal, and Spain due to revisions

\footnotetext{
1 The author's affiliation is indicated as at the time of this paper's submission for consideration. This paper is solely the opinion of the author and does not necessarily reflect the official position of the Bank of Russia. The Bank of Russia assumes no responsibility for the content of this work.
} 
of their sovereign credit ratings and investors' reassessment of the risks associated with investing in their debt. The revision of Greece's credit rating also echoed the dynamics of yields in other Eurozone countries with high budget deficits (De Santis, 2012). In addition, indicators of sovereign risk, such as credit default swaps (CDS) or government bond yield spreads, aggregate information on the global macroeconomic situation and on financial markets, which helps forecast various economic and financial variables for a country (Xiao et al., 2019). Thus, the assessment of sovereign default risk, the perception of that risk by economic agents, and the macroeconomic factors determining it are important parts of the analysis of the economic conditions in a country. The impact of sovereign risk on monetary conditions determines the importance of these tasks to the central bank in the conduct of monetary policy.

This paper aims to identify the determinants of Russia's sovereign risk. For this purpose, an optimal measure of sovereign risk for Russia - the spread on sovereign CDS - was selected, and an empirical analysis of the impact of various factors on the spread was carried out. Based on the existing literature, a number of factors were selected that could potentially influence sovereign risk. Using an autoregressive distributed lag (ARDL) model and a cross-validation algorithm, the factors that best predicted CDS outside the training sample were selected. The implied volatility of the rouble exchange rate and the size of Russia's foreign exchange reserves to GDP are among the local factors affecting CDS. The average of the CDS spreads of other emerging market economies (EMEs) was selected as a proxy for global factors, for which determinant analysis was also performed using a similar methodology. Significant factors for EME CDS are the volatility of the EME currencies, the slope of the US government bond yield curve, as well as the increments of the dollar index. The analysis is supplemented by an estimate of the equilibrium level of CDS spread under the given factors, which allows conclusions to be drawn regarding what level of CDS can be expected in the future if the short run factors not included in the model cease to have an impact on the spread. A historical decomposition of the dynamics of CDS by factor is also provided.

The large number of potential factors considered to explain CDS dynamics, as well as the method of factor selection based on the accuracy of the model's out-ofsample predictions, set the proposed method apart from those used in similar works.

\section{Sovereign risk measures}

One of the most common measures of sovereign risk is credit ratings: they date back to the early 20th century and have gradually been adopted by investors and regulators around the world. Rating agencies assess the credit risk of corporate and public debt instruments by aggregating a large amount of relevant information and assigning credit ratings based on it. The agencies regularly review the ratings and publish their methodology and criteria. At the same time, there are a number 
of significant drawbacks of credit ratings: the agencies are focused only on assessing long-term risks, so they rarely revise their ratings and are slow to adjust to changing situations, the assessment methods are not always transparent, and the potential conflict of interest which is involved in the business model of the rating agencies may contribute to the distortion of assessments (White, 2010).

Credit risk indicators based on financial market instruments are an alternative to credit ratings; these are much more responsive to new information (Rodríguez et al., 2019) and, because they reflect market participants' view of default risk, have a meaningful impact on other sectors of the financial market. For example, the market yield on an issuer's bond also reflects the issuer's credit risk, as the higher the risk, the greater the compensation in the form of yield demanded by the creditor. The spread of that yield against a risk-free yield in the same currency and of the same maturity is an indicator of risk (the spread may also include a premium for other risks, such as liquidity risk - see below). Generally, for sovereign issuers, risk is measured relative to foreign currency liabilities (Eurobonds), most often in USD, and the risk-free rate is the yield on the US government bonds, which are almost entirely free of credit risk. This is because, historically, foreign currency debt has been considered the main source of funding for EMEs, while default on debt in the local currency can be avoided by money issuance. Reinhart and Rogoff $(2008,2011)$ argue against this by showing that local currency debt accounts for a larger share of government borrowing and that defaults on it are slightly less frequent than on foreign currency debt, which does not always take precedence over local currency debt.

$\mathrm{Du}$ and Schreger (2016) also note that the share of foreign investors in local EME debt has increased significantly in recent years, and that the Eurobond market is becoming less liquid. Another reason to use foreign currency debt to assess the sovereign risk of EMEs is the difficulty of estimating the risk-free rate in local currency. One possible proxy for this risk-free rate is the yield on bonds issued by supranational institutions with top credit ratings (World Bank, European Investment Bank, German state bank Kreditanstalt für Wiederaufbau) in EMEs currencies. The disadvantage of this method is the lack of a liquid market for these bonds. Du and Schreger (2016) suggest using the interest rate on cross-currency swaps as an alternative. A cross-currency swap allows an investor to hedge currency risk by exchanging the income from holding a government bond in the issuer's local currency for USD payments. The interest rate paid by the investor in this case includes the foreign exchange risk premium, but does not include the credit risk premium, as the payments are made bilaterally. Thus, the difference between the local currency yield on the government bond and the cross-currency swap interest rate reflects the default risk premium. By comparing the estimates of the risk-free rate in the local currencies of individual countries with the yields in the same currencies on bonds issued by supranational institutions, the authors conclude that these estimates are close and highly correlated. The risk premiums on local currency debt and USD debt are correlated, but the spread between them is in most 
cases significantly negative. The lower risk premium on local currency debt can be explained by the fact that hedging currency risk through a swap results in a lower loss for the investor in the event of default due to the positive correlation between credit risk and the exchange rate. The difference in the expected frequency of default on local and foreign currency debt, capital flow constraints, compliance risks, and the existence of USD liquidity shortages may also explain the difference in risk premiums across currencies as financial market frictions. The authors show that local debt is more liquid, but more prone to segmentation between the external and domestic debt markets, foreign exchange market frictions, and short-selling restrictions. Amstad et al. (2020) calculate a similar measure of credit risk for local currency debt using the credit ratings on the debt and conclude that the spread between local and foreign currency credit risk has steadily declined in recent years due to rising foreign exchange reserves, countries' reduced dependence on foreign currency borrowing, and lower volatility in the global markets.

Credit risk can also be assessed using CDS, financial derivatives that allow insurance against default on bonds (or other credit events that result in the borrower's defaulting on its obligations when due) for a specified period. The buyer of the contract makes regular payments in the amount of the spread (premium) on the contract expressed in basis points (bp; annualised), and the seller undertakes to compensate the buyer's losses in the event of default (the difference between the market value and the face value of the bond). Thus, the CDS spread reflects the cost of insurance against default - the higher the probability of default, the larger the spread will be. The main asset underlying sovereign contracts is foreign currency bonds, and a default on local debt does not constitute a credit event for the enforcement of the contract. Sovereign CDS can be denominated in different currencies, including the local currency, but are most often denominated in USD (for the US, in euros), because in the event of default, a significant weakening of the local currency can be expected, resulting in additional losses for the buyer of the contract. This risk is embedded in the quantum spread - the spread between CDS premiums denominated in different currencies (Augustin et al., 2018). CDS contracts are traded over the counter, but they are partly standardised - e. g., coupon payments are usually made on the 20th of every third month, ${ }^{2}$ and expiry and transfer to new contracts occur once every six months, ${ }^{3}$ which can be a source of seasonality in CDS trading. The most liquid term for CDS is five years (Culp et al., 2016). Depending on the terms of the contract, a CDS can hedge not only the default risk of one single borrower (a single-name CDS) but several at once (a multi-name CDS); there are also standardised index CDS, such as CDX and iTraxx.

In the absence of arbitrage, CDS and bond spreads should be equal (Duffie, 1999): the yield on a portfolio of a risky bond and a CDS on that bond is risk-free

\footnotetext{
${ }^{2}$ On the IMM dates (international monetary market) - 20 March, 20 June, 20 September, and 20 December.

${ }^{3}$ Expiry on 20 June and 20 December, and transfer to a new contract on 20 March and 20 September.
} 
because the credit risk is hedged by the CDS, so the CDS premium paid by the buyer is equal to the difference between the risky and risk-free yields. In practice, however, there is a gap between them, due to the costs associated with arbitrage (Gyntelberg et al., 2013), the difference in liquidity and counterparty risk between the two markets (Longstaff et al., 2005), the existence of a CTD option in the CDS contract for the contract buyer (Ammer and Cai, 2011), and other factors.

There is no consensus in the literature as to whether CDS or Eurobond spreads more accurately reflect country risk, although, for the corporate sector, research has confirmed that the CDS market is more informationally efficient (Augustin et al., 2014). For EMEs, earlier studies show that CDS react to events with a lag compared to that of bonds (Li, 2009), which may be due to the low liquidity in the CDS market when they first started trading. Later papers report mixed results for different countries and periods (Aktug, 2014; Ammer and Cai, 2011; Coudert and Gex, 2013; Hassan et al., 2015; Li and Huang, 2011), and they do not allow an unambiguous conclusion in favour of a particular market to be drawn. The results of a recent study by Raja et al. (2020) show that the CDS market performs better for all eight countries covered in the analysis, including Russia, on a sample of 2006-2016. The authors attribute this to the higher liquidity of the CDS market compared to the bond market, which they confirm empirically by analysing the bid-ask spreads of CDS and bonds. The advantage of using bond spreads is the availability of longer data series, as CDS contracts only became common in the 2000s. At the same time, CDS contracts are rather standardised and traded at fixed maturities of mostly 5-year terms (Aldasoro and Ehlers, 2018), while the maturity of Eurobonds, their liquidity at different maturities, and the contract parameters vary, which makes it difficult to calculate the fixed-term risk premium and compare it between different countries.

CDS are traded over the counter, as are bonds for the most part, so it is difficult to accurately estimate the volume of trade in these markets. According to EMTA survey data on sovereign and corporate CDS and EME bonds, turnover in the CDS market in 2019 was $\$ 1.8$ trillion, turnover on debt was $\$ 5.3$ trillion, of which $\$ 2.3$ trillion were Eurobonds and \$1.3 trillion were sovereign Eurobonds. According to the Bank for International Settlements, ${ }^{5}$ the nominal size of the CDS market in the second half of 2019 was \$1.2 trillion. The Eurobond market in 2019Q4 was $\$ 2.0$ trillion, of which $\$ 1.3$ trillion was in EMEs.

Russia's sovereign risk indicators are shown in Figure 1: 5-year sovereign USD CDS, the 5-year spread on OFZ (federal loan bonds) and the US government bond yields, the 5-year spread on OFZ and cross-currency swap (XCCY) yields, and Russia's long-term foreign currency credit rating (an average of Fitch, S\&P,

\footnotetext{
4 The Emerging Markets Traders Association (EMTA) publishes data on the trading turnover of debt and CDS in emerging markets; the data are provided as part of a survey of market participants. The data on turnover in the debt market are provided by 50 market participants. The data on CDS trading volume data includes 23 countries and 9 corporate issuers and is provided by 12 major international banks and broker-dealers. See https://www.emta.org/activities-and-services/volume-surveys/

5 See https://www.bis.org/statistics/index.htm
} 
and Moody's ratings). The dynamics of CDS and the spread on government bond yields are broadly similar, as is expected theoretically, but the difference between them becomes significant in particular periods. The credit rating also has similar dynamics, but lags behind the CDS and the yield spread. The indicator for the sovereign risk of the rouble, the OFZ-XCCY spread, takes lower values, which is consistent with the conclusions drawn in the literature.

The CDS spread is one of the most common measures of sovereign risk in the literature; CDS are convenient to use in analysis as they are traded at fixed maturities. There is a relatively long series of data available, unlike for cross-currency swaps, CDS are a market-based measure of risk and are not subject to distortions such as credit ratings, and there is empirical evidence that the CDS market is more liquid and informationally efficient than the Eurobond market. For these reasons, it is Russia's CDS spread that is analysed further in this paper. The most liquid contracts are 5-year contracts in USD, and that is why they were chosen.

Figure 1. Russia's sovereign risk indicators

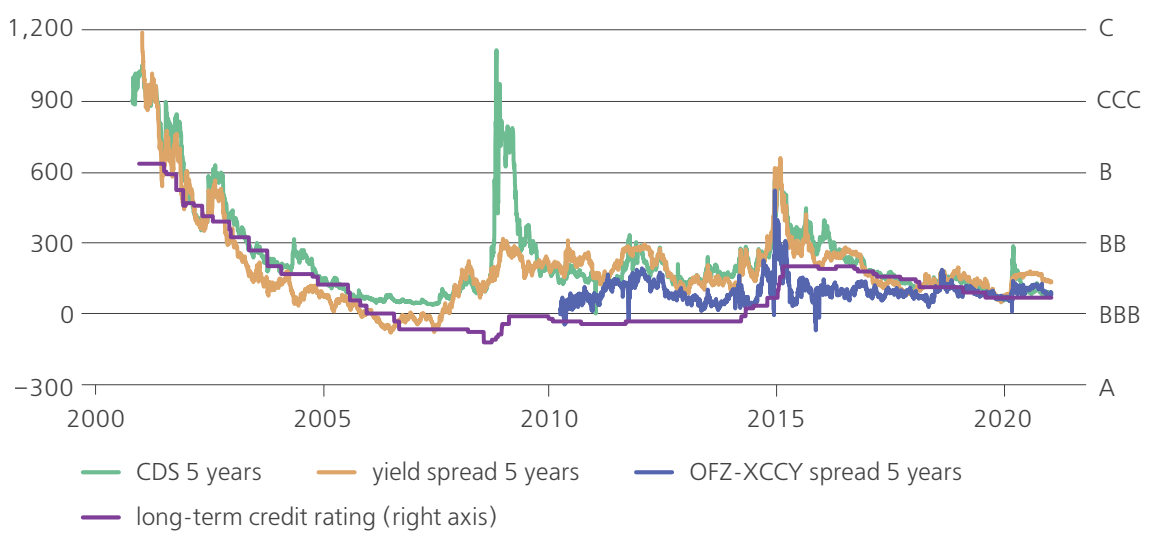

Source: Refinitiv, Bloomberg, Cbonds, author's calculations

\section{Literature review}

\subsection{CDS determinants}

There has been a lot of research on the factors affecting CDS. The determinants of sovereign CDS can be divided into global, those which are common to many or even all countries, and local (regional or country-specific). One reason for the interest in searching for global factors is the frequent synchronicity of spread movements, which is especially noticeable during global shocks. Thus, Augustin (2018), Augustin and Tédongap (2016), Longstaff et al. (2011), and Pan and Singleton (2008) have shown that $57-96 \%$ of the dynamics of CDS in different countries can be explained by the first main component. At the same time, local 
factors such as debt, foreign currency reserves, and the country's other macro fundamentals also influence sovereign CDS spreads.

Sovereign solvency. The ability of a state to meet its debt obligations directly affects its credit risk and is determined by the dynamics of public debt and the assets that can be used to service it. The state of public finances (budget deficit, debt-to-GDP ratio), the external position of the state (foreign currency reserves, current account balance, and trade balance), and economic growth (change in real output, consumption, and investment) are distinguished as factors. The theoretical justification for the influence of these factors is provided, for example, by Edwards (1983, 1986); empirically, the importance of these factors has been confirmed in a large number of papers (e.g., Baek et al., 2005; Beck, 2001; Kocsis and Monostori, 2016; Plank, 2010). Additionally, CDS are influenced not only by the actual values of the indicators themselves, but also by the expectations economic agents have for them. Typically, quantitative analysis uses analysts' consensus to account for this factor, or the prices of various assets in the financial market, which aggregate information on the expectations of a large number of market participants. In addition, the volatility of government assets also necessarily has an influence on sovereign risk, as the risk of default increases when volatility increases. According to Merton's model (Gray et al., 2007), the level of sovereign risk is also affected by exchange rate volatility. Borio and Packer (2004) also identify the state's past ability to manage moderately high levels of debt, the ability to borrow abroad in its own currency, and the sensitivity of the net income of the state to changes in the exchange rate as statistically significant factors.

Political stability and institutional development. Sovereign risk tends to be lower in globally integrated economies with strong institutions and high political stability (Eichler, 2014; Kocsis and Monostori, 2016). The transition to an inflation targeting regime also reduces sovereign risk (Balima et al., 2017).

Stability of banking sector. Crises in the banking sector often precede sovereign defaults (Laeven and Valencia, 2013): first, state measures for the financial support of banks can contribute to sovereign credit risks; second, problems in the banking sector lead to economic crisis and the deterioration of public finances. The significance of this factor has been empirically confirmed, in particular by the European debt crisis (Kallestrup et al., 2016; Kocsis and Monostori, 2016; Sgherri and Zoli, 2011).

Investors' risk tolerance. The more investors in global markets avoid risk, the higher the risk premiums they demand, leading to an increase in credit risk indicators in the financial markets (Remolona et al., 2008). The literature also notes that this factor's role has increased in recent years, and its significant effect on credit spreads during the onset of crises and in the absence of crises, while during a crisis local factors have a more significant impact (Arghyrou and Kontonikas, 2012; Caceres et al., 2010).

Transmission of risks between countries. Economic linkages between countries, correlation of the business cycles in different countries, and the integration 
of financial markets contribute to the spread of credit risk between them. Bai et al. (2012) confirm the spread of credit risk due to correlations between the fundamental factors in different countries. Benzoni et al. (2015) show that in the event of a negative shock in one country, investors revise their estimates of the probability of default in other countries in the face of information uncertainty. Ismailescu and Kazemi (2010) find that a change in one country's credit rating affects not only its CDS spread, but also, if the rating is upgraded, the spreads of other countries, particularly those with creditors in common with that country. The integration of the financial markets of different countries with the US market can also lead to the proliferation of risks: Wang and Moore (2012) confirm the integration of CDS markets and note the US interest rate factor as the key to explaining the increasing correlation of markets with the US market, while Dooley and Hutchison (2009) find that different US financial and economic news has significant influence on the CDS spreads of EMEs.

\subsection{Russian sovereign risk}

Longstaff et al. (2011) highlight the determinants of sovereign CDS, looking at the variables of the financial market, and estimate the size of investors' risk avoidance premium using a reduced-form model for CDS on a sample from 2003-2010. They find that Russian CDS are significantly dependent on local (the equity index, the exchange rate, and the size of the foreign exchange reserves) and global (the US equity index, the US high yield corporate bond index, the difference between the implied and realised volatility of the S\&P, the risk premium on the US government bonds, capital flows, and the CDS spreads of other EMEs) factors. Local factors influence Russian CDS to a greater extent than the average for the group of countries studied: the share of variation explained is about $60 \%$, while the average for all the countries is about $40 \%$. The share of the risk premium in Russian CDS is about $2 / 3$ (on average, it is $1 / 3$ in EMEs). At the same time, both components of the spread are well explained by the dynamics of global factors $\left(R^{2}=0.6-0.7\right)$.

Plank (2010) proposes a model in which the CDS spread depends on the macroeconomic fundamentals determining the solvency of the state: the state's level of external debt and its ability to repay the debt, which is determined by the level of foreign exchange reserves and the net inflow of foreign currency into the country. Applying this model to the spread on Russian CDS in a 2002-2010 sample, the author satisfactorily explains its dynamics (mean absolute error -87 bp). At the same time, the actual CDS spread is generally higher than that in the model, and the implied level of foreign exchange debt is higher than the actual level (by $30 \%$, on average). This may be due to the fact that the available data on debt does not fully reflect its true size due to the possible existence of debt in the form of guarantees or subsidies.

Li et al. (2014) identify the risk premium for a downgrade of the credit rating in the CDS spread by simultaneously modelling the CDS spreads of a set of countries 
and taking their credit ratings into account. On a 2004-2012 sample, they find that, for a likely change in Russia's credit rating, the premium in the Russian CDS spread is only $1-2 \%$, while the premium for the probability of default (explained by the credit rating) accounts for most of the spread. The authors also find that the dynamics of Russian CDS are for the most part explained by global factors (a common factor across all countries helps explain $76 \%$ of Russia’s CDS variation).

Empirical analyses of the determinants of Russia's sovereign risk have also been conducted by Chuffart and Hooper (2019), Ertugrul and Ozturk (2013), Kocsis and Monostori (2016), and Stolbov (2017). Among the relevant factors are various global and regional risk indicators (the Volatility Index of the Chicago Board Options Exchange (VIX), the CDS spreads of other countries, etc.) and some local macroeconomic factors (the rouble exchange rate, the size of foreign exchange reserves, the index of the Russian equities market, the oil price, and changes in Russia's credit rating), however, not all of the studies confirm significance of each of them. Ertugrul and Ozturk (2013) consider only financial market factors as determinants of the CDS of different EMEs and find that the Russian CDS spread is significantly affected by the VIX, the volatility of CDS, and the EMBI+ index for Russia in both the short and long run, and by the Russian equity market index in the short run. Stolbov (2017) includes macroeconomic factors in the list of potential variables as well, but does not include, for example, the size of the external debt, the size of the budget surplus, exchange rate volatility, or the real price of oil. He finds that global factors have a greater impact on Russian CDS than local factors; in the long run, CDS are influenced by the VIX, the TED spread, the exchange rate, and changes in Russia's credit rating by Fitch, and in the short run by the price of oil and the size of foreign exchange reserves. Kocsis and Monostori (2016) use a large number of different factors in the model, combining them into five groups, but they do not consider the impact of each factor on CDS separately. They learn that local factors have a more significant impact on CDS. Spreads are most influenced by institutional, political, and public finance factors. Russian CDS on average matched the average spread for EMEs as a result of a strong external trade position due to high energy exports and despite the weakest institutional and political factors among all countries in the sample. Chuffart and Hooper (2019) analyse only the impact of oil prices on the CDS of Russia and Venezuela. According to their paper, oil prices do not have a meaningful direct impact on Russian CDS, which the authors attribute to the existence of the exchange rate channel. The equity markets in Russia and the US have significant impact on spreads, more so during periods of high volatility. The exchange rate affects CDS only in periods of low volatility.

This paper uses a large number of potential factors in the analysis of CDS determinants and takes their out-of-sample forecast accuracy into account in their selection, which distinguishes the proposed method from similar papers and allows for different results: thus, unlike Stolbov (2017), in the model, long-term 
CDS are significantly affected by exchange rate volatility and foreign exchange reserves, the EME CDS spread is included as a global factor instead of the VIX and TED spread, and Russia's credit ratings do not help forecast CDS. Thus, while in Stolbov's (2017) model macroeconomic factors can be influenced indirectly through credit ratings, in this paper, it is possible to estimate the impact of foreign exchange reserves directly. In addition to analysis of determinants, this paper also provides estimates of a 'fair' CDS level for given factor values and a historical decomposition of CDS by factor.

\section{CDS determinants}

To assess the impact of various factors on Russia's sovereign risk, a model was implemented in which Russian CDS depend on various global and country factors. The choice of potential explanatory factors was based on the literature on CDS and sovereign risk. Among these factors are a large number of local variables that characterise Russia's sovereign risk, as well as two proxy variables of global factors that affect the CDS of many countries: the EME CDS and VIX, of which only the EME CDS was found to be significant for Russian CDS. An ARDL model was used as the base model. The selection of factors was carried out by estimating the accuracy of out-of-sample prediction in the model as part of cross-validation. In order to determine which global factors affect the CDS of Russia and the CDS of EMEs as a whole, a model for EME CDS with different global factors was built using the same methodology.

\subsection{Data}

Model for Russian CDS. Data on Russia's 5-year sovereign CDS spread were used for the analysis of Russia's sovereign risk. In order to ensure a sufficient sample size, the analysis was conducted using monthly data from January 2012 to August $2020 .^{6}$ In this sample, the average CDS spread was $194 \mathrm{bp}$, reaching $567 \mathrm{bp}$ at the maximum and $60 \mathrm{bp}$ at the minimum, with a standard deviation of $92 \mathrm{bp}$. Potential variables for the model were selected based on the literature review in Section 3.

1. Global factors. The high correlation between the CDS of different countries has often been noted in the literature, which is explained by their common dependence on various global financial and macroeconomic factors (see Section 3). The model includes the two variables that may most effectively reflect the influence of these factors:

1.1. The EME CDS Index (CDSEM) reflects the country-specific risk of the EMEs. A similar proxy variable for global factors has been used, e. g., by Longstaff et al. (2011). The average EME CDS and its standard deviation

\footnotetext{
${ }^{6}$ The beginning of the sample (2012) is due to the availability of data on the state budget surplus.
} 
in the sample were lower than the average Russian CDS, at 135 bp and $35 \mathrm{bp}$, respectively.

1.2. The Volatility Index of the US equity market (VIX) is widely used as a proxy for global risk demand. For example, it has been used in the modelling of CDS by Chuffart and Hooper (2019) and Stolbov (2017). The average VIX in the sample is 16.4, with a standard deviation of 6.3.

2. Country-specific macroeconomic factors. The macroeconomic situation in a country determines the ability of the state to repay debt. To account for this, five main factors which reflect the solvency of the country have been chosen in the model (Kocsis and Monostori, 2016; Plank, 2010) as well as other macroeconomic factors (Kocsis and Monostori, 2016; Stolbov, 2017).

2.1. External debt to GDP ratio $(\boldsymbol{E X})$. This indicator has a direct impact on the probability of default: the larger the amount of debt, all other factors being equal, the harder it is for the state to repay it in the future. Russia's external debt is relatively low, ranging from 17 to $41 \%$ of GDP in the sample studied, with an average value of $29 \%$ of GDP.

2.2. Foreign exchange reserves to GDP (RES), general (SUR) and non-oil and gas (SURNO) surpluses of the state budget to GDP, export-toimport ratio (TRADE). These factors reflect the state's ability to repay debt: a higher volume of foreign exchange reserves, budget surpluses, and foreign exchange inflows to the country through the trade balance means a greater amount of state assets that can be used to repay external debt. The foreign exchange reserves to GDP ratio is quite high, averaging $27 \%$. The overall budget surplus is about $0 \%$ on average, the non-oil and gas surplus is negative on average, at $-8 \%$. Russia's exports are high relative to imports: this ratio took a level of 1.6 on average and did not fall below 1.2.

\subsection{Inflation (INFL) and the Goldman Sachs Current Activity Indicator} (CAI) are indicators of macroeconomic stability in the country. The CAI index was selected as a proxy for the real GDP growth rate, for which monthly data are available. The index reflects the month-onmonth annualised growth rate and averages $1.2 \%$ in the sample. Inflation may be important to Russian CDS due to the transition to inflation targeting. The average inflation rate month-on-month is $0.5 \%$ in the sample, but inflation has declined in recent years compared to the period before the transition to the inflation targeting regime in 2014.

2.4. Real oil price $(O I L)$. The oil market has a significant impact on the financial markets and the real economy of Russia, a major oil exporter. The oil price may have additional explanatory power, as other fundamental factors (reserves, exports, etc.) react to changes in it, with a lag. 


\section{Financial market factors.}

3.1. The 3-month implied volatility of the exchange rate (VOL). Exchange rate volatility determines the volatility of state assets and the ability of the state to meet its obligations, according to Merton's model (Gray and Malone, 2008). The more volatility there is, the greater the uncertainty about the future dynamics of assets, and the higher investors' current assessment of credit risk. Exchange rate volatility can also reflect factors that are difficult to account for quantitatively, but which may affect the future state of the economy and are already embedded in the prices of financial assets, e.g., geopolitical risks. Volatility has been used in modelling Russian CDS by Stolbov (2017), for instance; instead of exchange rate volatility, Chuffart and Hooper (2019) include changes in the exchange rate in their model, as the oil price can influence CDS through it, but in terms of theory, it is more correct to use volatility, and volatility also responds to changes in oil prices. The volatility of the exchange rate in the sample studied was $14 \%$, reaching $8 \%$ at the minimum (2013) and 52\% at the maximum (early 2015).

3.2. Changes in the Moscow Exchange Index (MOEX). Since the different segments of the financial market are interconnected, the model also includes the Russian equity market index (Ertugrul and Ozturk, 2013; Chuffart and Hooper, 2019). The index is included in percentage changes because it is the growth rate of the stock index that determines the state of the equity market. The average growth rate of the index month-on-month was $0.7 \%$ and the standard deviation was $4.4 \%$.

4. Credit ratings (RATE) (average of Fitch, Moody's, and S\&P ratings) can carry additional information about credit risk for market participants, so a change in rating can lead to adjustments to CDS. The average rating for Russia in the sample was 9.7 (between BBB- and BBB according to S\&P and Fitch).

All variables except the CAI and the budget deficit, which can take negative values, were included as logarithms (for the MOEX index, the difference in the logarithms of the index). Russian CDS, as well as almost all of the explanatory variables (taking into account transformation) are non-stationary. For a detailed description of the variables and sources of data, see Table 5 in the Appendix to the online version of this paper; for descriptive statistics, see Table 7 in the Appendix.

Model for the EME CDS. For the EME CDS model, monthly data for the period from January 2005 to August 2020 was used. Among the potential explanatory factors, the following were selected:

- The volatility index of the US equity market (VIX). As noted above, the VIX is often used as a measure of investor risk tolerance. It averaged 18.9 over the period from January 2005 to August 2020.

- The 3-month implied volatility of the EME exchange rates against the USD (VOLEM) is included in the model by analogy with the model for 
Russian CDS. The volatility of the EME exchange rates was $10 \%$ on average, with a standard deviation of $3 \%$.

- The EME CAI Index (CAIEM). This index reflects the macroeconomic situation in the EMEs. It averaged $4.2 \%$ with volatility of $2.4 \%$.

- The yield on 10-year US government bonds (UST10Y) and the slope of the yield curve of the 10-2 year US government bond spread (UST10Y2Y). These factors can affect CDS through different channels. First, changes in the yield curve of government bonds reflect changes in the US macroeconomic situation, which translates into economic conditions in other countries, thereby possibly influencing the CDS of those countries. Second, the US government bonds are often referred to as a defensive asset, for which demand rises at times of rising global risk, which are typically accompanied by rises in CDS. Third, rising interest rates in the US also increase the cost of the USD-denominated borrowings, which may increase the EMEs sovereign risk. The average yield for 10 years was $2.9 \%$, and the slope was $1.2 \%$ with a minimum value of $-0.15 \%$ (corresponding to the inverted yield curve).

- The Dollar Index (DXY). During periods of rising global risk, there is also an increase in demand for the USD, since it is a major reserve currency. In addition, the strengthening of the USD may directly increase sovereign risks for EMEs due to an increase in the cost of external borrowing. Therefore, the USD exchange rate index DXY in percentage changes is included in the model (the exchange rate itself should not affect CDS, as it is determined by a large number of economic factors and the economic situation adjusts to exchange rate changes over time, but exchange rate changes can be a consequence of rising or falling risks and lead to increased risks to EMEs). The average growth rate of the index in the sample studied was $0.1 \%$, the strongest weakening of the USD was $2.8 \%$, and the maximum strengthening was $4 \%$.

All variables except the CAI index and the slope of the yield curve were included as logarithms (for the DXY index, the difference in the logarithms of the index). The EME CDS and some of the explanatory variables are also nonstationary. See Table 6 in the Appendix for a detailed description of the variables and data sources, and Table 8 in the Appendix for descriptive statistics and results of the stationarity tests.

\subsection{Methodology}

ARDL model. Since some of the variables in each model are non-stationary and some are stationary, the ARDL model of Pesaran and Shin (1999) for estimating the effect of these factors on CDS was chosen. This allows the estimation of the co-integration relationships between the integrated and stationary variables, including in the presence of endogeneity. This model has also been used by Stolbov 
(2017) and Ertugrul and Ozturk (2013). This approach is convenient in that it allows the estimation of the level of CDS that should form at given values of the determinants. If, instead, the differences of variables were taken in order to achieve stationarity and build a simple regression, such estimates would not be possible.

In the model, the explained variable depends on its own lags, as well as on the current values and lags of the exogenous variables:

$$
y_{t}=\phi+\sum_{i=1}^{p} \alpha_{i} y_{t-i}+\sum_{j=1}^{k} \sum_{l=0}^{q_{j}} \beta_{j, l_{j}} x_{j, t-l_{j}}+\varepsilon_{t},
$$

where $y_{t}$ is the explained variable, $x_{j, t}$ is an explanatory variable, $\varepsilon_{t} \sim N\left(0, \sigma^{2}\right), p$ is the number of lags of the CDS, $q_{j}$ is the number of lags of the $j$-th explanatory factor, and $k$ is the number of explanatory variables. This model can be represented in the form of an Error Correction Model (ECM), i.e. in the form of two relationships between variables, short-term (temporary) and long-term $\left(L R_{t}\right)$ :

$$
\begin{gathered}
\Delta y_{t}=c+\sum_{i=1}^{p-1} a_{i} \Delta y_{t-i}+\sum_{j=1}^{k} \sum_{l=0}^{q_{j}-1} b_{j, l_{j}} \Delta x_{j, t-l_{j}}+\gamma E C_{t-1}+u_{t}, \\
E C_{t}=y_{t}-L R_{t}, \\
L R_{t}=c_{L}+\sum_{j=1}^{k} b_{L j} x_{j, t} .
\end{gathered}
$$

In the ECM model, the long-term (co-integration) relationship $\left(L R_{t}\right)$ reflects a certain equilibrium between the variables that is formed in the long term without shocks. In the short term, the dependent variable may deviate from the long-term equilibrium as a result of the impact of temporary factors: these can be both shortterm effects of the explanatory variables $\left(b_{j, l_{j}}\right)$ which differ from long-term effects $\left(b_{L j}\right)$, or the factors' impact absent in the model. When deviating from equilibrium, the dependent variable returns to equilibrium at the rate set by parameter $\gamma-$ for this purpose, it must be negative. Testing for the presence of a long-term ratio is performed using the F-bounds test. This is an F-test that tests the null hypothesis $H_{0}:\left(\gamma \cap\left\{b_{L j}\right\}_{j=1}^{k}\right)=0$ (no long-term relationship) against the alternative hypothesis $H_{1}:\left(\gamma \cap\left\{b_{L j}\right\}_{j=1}^{k}\right) \neq 0$. The F-statistic calculated is compared to the critical values corresponding to two opposite cases: when all variables are I(0) (lower bound) and when all are I(1) (upper bound). If the statistic is less than the lower bound, the hypothesis of no co-integration cannot be rejected. If the statistic is higher than the upper bound, the null hypothesis is rejected and the presence of co-integration is confirmed. In other cases, it is impossible to draw conclusions from the test.

The number of lags in the model was determined based on the Schwartz criterion with the maximum number of lags for each variable equal to 4 months.

The ARDL model was used for both the Russian CDS modelling $\left(y_{t}=C D S_{t}\right)$ and the EME CDS modelling $\left(y_{t}=\operatorname{CDSEM}_{t}\right)$. 
Selection of factors. The selection of the factors for both models was carried out by selecting models with different combinations of factors based on root mean square error (RMSE) calculated as part of type of cross-validation algorithm. Cross-validation was used to estimate the predictive accuracy of the model as accurately as possible while avoiding the impact of random effects on this estimate. Thus, the RMSE was calculated for terms from one month to three years in the model with the end of the sample floating for training. That is, on a sample up to time $T$, a model with set of factors $j$ was estimated up to $T-36$, a forecast was made for the period from $T-35$ to the end of the sample, the RMSE was estimated for each period ( 1 month, 2 months, ..., 36 months), then model $j$ was evaluated up to $T-35$, the RMSE was calculated for all available periods ( 1 month, ..., 35 months), and so on, up to $T-1$ (with an error of 1 month). Thus, one forecast was obtained for 36 months, two forecasts for 35 months, ..., 36 forecasts for 1 month. After that, the RMSEs were averaged for each period. The RMSE for all periods was also averaged, which allows a single estimate of the forecast quality of the model. The disadvantage of the chosen method is that the number of forecasts for longer periods is less than the number of forecasts for shorter periods, so their estimates may be offset. However, this method is optimal for small sample size (a total of 104 points in the model for the Russian CDS), which does not allow the use of more iterations of the model estimation for earlier periods. Similarly, the maximum number of factors in the model was limited to six (also due to the long time required to process models with larger numbers of factors). In addition to the criterion for minimising the RMSE, a restriction on the significance of all factors in the model (p-value less than 0.01 ) and the presence of co-integration (in accordance with the bounds test) was also used.

\subsection{Results}

Model for Russian CDS. A model with three explanatory factors was selected: the EME CDS index, exchange rate volatility, and the ratio of foreign exchange reserves to GDP (the full specification is given in Table 9 in the Appendix). All variables significantly affect CDS in the long term, the signs of the coefficients correspond to those expected. Growth of the EME CDS and the volatility of the exchange rate by $10 \%$ lead to an increase in the CDS by $8.3 \%$ and $5 \%$, respectively, and the growth of the reserves-to-GDP ratio by $10 \%$ leads to a decrease in CDS by $14.1 \%$ (Table 1). In the short run, CDS are influenced only by the EME CDS and the exchange rate volatility. Adjustment to long-term equilibrium occurs fairly quickly: half the gap between actual CDS and the long-term equilibrium closes in 1.5 months (Table 2). The long-term ratio explains CDS dynamics well $\left(R_{2}=0.93\right)$. Co-integration in the model according to the F-bounds test is at the $1 \%$ level of significance. The average RMSE for the forecast, conditional on the dynamics of the exogenous variables, was $19 \mathrm{bp}$ (from 9 to $29 \mathrm{bp}$ for terms from 1 month to 3 years). 
Table 1. Long-term relationship $(L R)$ from ARDL model for Russian CDS

\begin{tabular}{lllll} 
Variable & Coefficient & Standard error & t-statistics & p-value \\
\hline$C D S E M_{t}$ & 0.83 & 0.10 & 8.55 & 0.00 \\
\hline$V O L_{t}$ & 0.50 & 0,06 & 8.04 & 0.00 \\
\hline$R E S_{t}$ & -1.41 & 0,11 & -13.06 & 0.00 \\
\hline$c$ & -2.06 & 0.43 & -4.82 & 0.00
\end{tabular}

Specification: $C D S_{t}=0.83$ CDSEM $_{t}+0.5 \mathrm{VOL}_{t}-1.41 \mathrm{RES}_{t}-2.06+v_{t}^{C D S}$.

Source: author's calculations

Table 2. Short-term relationship from ARDL model for Russian CDS

\begin{tabular}{lllll} 
Variable & Coefficient & Standard error & t-statistics & p-value \\
\hline$\Delta C D S_{t-1}$ & 0.23 & 0.07 & 3.18 & 0.00 \\
\hline$\Delta C D S E M_{t}$ & 0.75 & 0.06 & 11.63 & 0.00 \\
\hline$\Delta C D S E M_{t-1}$ & -0.46 & 0.09 & -4.92 & 0.00 \\
\hline$\Delta C D S E M_{t-2}$ & -0.03 & 0.06 & -0.52 & 0.00 \\
\hline$\Delta C D S E M_{t-3}$ & -0.23 & 0.06 & -3.95 & 0.00 \\
\hline$\Delta V O L_{t}$ & 0.36 & 0.05 & 7.14 & 0.00 \\
\hline$E C_{t-1}$ & -0.38 & 0.06 & -6.18 & 0.00 \\
\hline
\end{tabular}

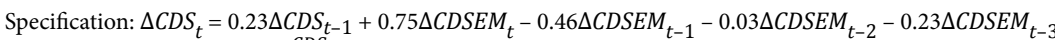
$+0,36 \Delta V O L_{t}-0.38 E C_{t-1}+u_{t}^{C D S}$.

Source: author's calculations

Figure 2. Russian CDS in ARDL model

a) actual and fitted CDS

from long-term ratio $(L R)$

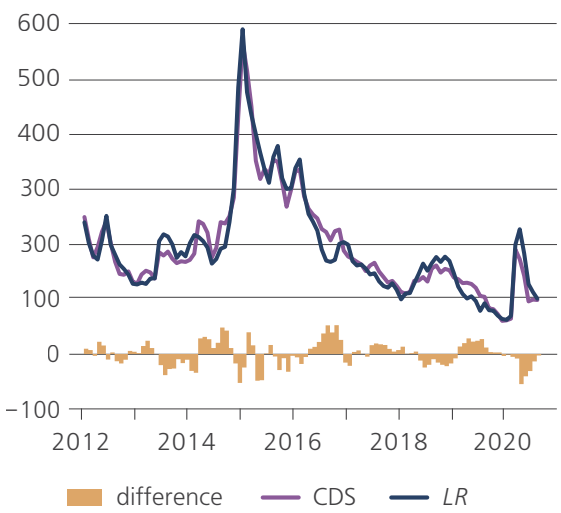

Source: author's calculations b) decomposition of CDS, $\%$ of cumulative total

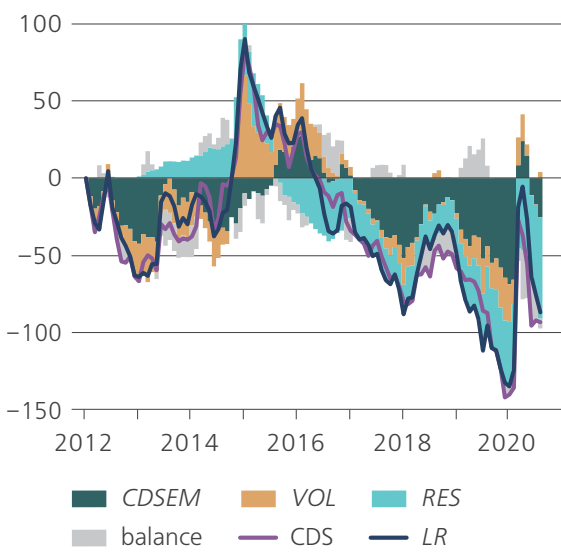

The fitted values of the CDS spread based on the long-term relationship and its comparison with the actual CDS spread, and a decomposition of the percentage increments of CDS by the cumulative total, are shown in Figure 2. In 2013-2014, 
the weakening of the rouble due to a decrease in oil prices was accompanied by a decrease in foreign exchange reserves, but due to global factors and a decrease in CDS, the EME CDS of Russia did not change significantly. In 2014-2015, a significant increase in CDS occurred as a result of a significant increase in exchange rate volatility in the context of a sharp weakening of the rouble. In 2016-2020, the decline in CDS was due to the stabilisation of the exchange rate, an accumulation of foreign exchange reserves, and a reduction of the credit risks of EMEs. In 2018, the growth of CDS occurred, first, in the context of an increase in exchange rate volatility due to the imposition of sanctions against Russian companies, and, second, due to a general increase in the risks to EMEs. In 2020, during the coronacrisis, exchange rate volatility and the EME CDS also increased, which contributed to the growth of CDS. At the same time, in the context of the maintenance of greater foreign exchange reserves than in 2014, CDS was formed at markedly lower levels.

Thus, the level of sovereign risk in Russia is significantly correlated with the situation in the EMEs. At the same time, local country factors explain the deviation of the dynamics of Russian CDS from the EME CDS. The currency crisis in 2014 and the introduction of sanctions against Russia in 2018 contributed to the growth of Russian CDS, and the introduction of the fiscal rule and the accumulation of foreign exchange reserves increased macroeconomic stability and reduced the country risks. According to the model, Russian CDS are significantly dependent not only on external factors (the global markets, the macroeconomic situation in the EMEs as a whole, and the foreign policy), but also on internal factors: the stabilisation of the foreign exchange market, the introduction of the fiscal rule, and the accumulation of foreign exchange reserves led to a noticeable decrease in Russian CDS. However, in the event of a further increase of foreign currency reserves in relation to GDP, the effect on sovereign risk will be noticeably smaller: while the growth of reserves from $30 \%$ to $40 \%$ in $2017-2020$ contributed to a reduction in CDS of around 60 bp $(-40 \%)$, an increase in reserves by a further 10 bp to $50 \%$ would reduce CDS by only 26 bp ( $-30 \%$ ) compared to August 2020 (CDS is equal to $98 \mathrm{bp}$ ). It should also be noted that the impact of exchange rate volatility was estimated on a sample that has been subject to a floating exchange rate regime for most of its existence (since 2014), and the change in volatility occurred mainly due to market factors. The positive effect of reduced volatility on CDS is explained, first, by the general increase in financial stability after the 2014-2015 crisis and, second, by a reduction in the impact of external factors such as sanctions. Both of these factors led to a reduction in exchange rate volatility, as well as in sovereign risk. Under a fixed exchange rate regime, the impact of volatility may differ markedly from the estimates obtained, or be absent, as in this case the exchange rate is not formulated by market.

Among the drawbacks of the model are: first, the potential endogeneity between Russian CDS and the explanatory factors (exchange rate volatility may increase due to increased credit risk, see Carr and Wu (2007); a weakening of the national currency due to increased credit risk leads to a fall in foreign exchange reserves under 
a fixed exchange rate regime) may make the interpretation of the model coefficients and decomposition difficult, although in general the resulting estimates of the effects of volatility have logical economic justifications. Second, the model's lack of factors that were not selected on the basis of the accuracy of the out-of-sample forecast does not mean that such factors do not affect CDS - it just means that their impact on sovereign risk in the approach used cannot be estimated accurately. This may be due, for example, to the fact that the influence of these factors varies over time, or their variation in the sample is too low. External debt was not selected as an explanatory factor. This can be explained by its low level in the period studied, but if it grows in the future, it may potentially affect CDS, which is not taken into account in the model. Nevertheless, the model describes the relationship between Russian CDS and the factors included well enough to allow qualitative and quantitative conclusions to be drawn from it, as well as a conditional forecast and scenario analysis.

Model for the EME CDS. The factors selected included exchange rate volatility, USD index changes, and yield curve slope (see Table 10 in the Appendix for the full specification). All variables are significant in the long term, and the null hypothesis of no cointegration is rejected at the $2.5 \%$ significance level. In the long term, a rise in exchange rate volatility and USD increments of $1 \%$ is expected to increase CDS, by $1.4 \%$ and $8.9 \%$, respectively. Slope growth of 10 bp leads to CDS growth of $1.7 \%$. In the short term, only the slope and the volatility are significant. The average RMSE for the forecast, conditional on the dynamics of the exogenous variables, was $17 \mathrm{bp}$ (from 9 to $23 \mathrm{bp}$ for terms from 1 month to 3 years). The EME CDS modelled based on the long-term relationship and the decomposition are shown in Figure 3. The model describes the data somewhat worse than the model for the Russian CDS, which is most likely due to the lack of a wide range of local factors in the model. However, the model explains, for example, the increase in the credit risks of the EMEs during the crisis of 2008 (increase in volatility and slope of the yield curve) and the crisis of 2020 (increase in volatility). The results obtained allow several conclusions to be drawn:

- The dependence of EME CDS on the DXY may mean that the CDS are affected by investors' attitude to risk: for example, investors' demand for 'safe' assets, which include assets in USD, increases in the event of various negative events; at the same time, these events increase the risks to EMEs. The factor of risk demand can also be taken into account in the model through the influence of exchange rate volatility.

- At the same time, it is the DXY that is significant in the model, not the VIX or the yield on the US government bonds, which are often used as a measure of investors' demand for risk. The significance of the DXY may be explained by the fact that a stronger dollar directly affects the debt risks of EMEs by increasing the cost of dollar-denominated borrowings.

- The slope of the US yield curve has a positive impact on EME CDS. This may be because the slope of the yield curve reflects a point in the US monetary policy cycle: when the slope increases, there is actual easing of monetary 
policy, by the FED in the situations of a worsening of the US economic conditions, which translates into or correlates with the economic situation in the EMEs, and a corresponding increase in risks (such as during the coronavirus crisis in 2020). If the increase in the slope of the yield curve reflected an increase in investors' demand for risk in the model, the effect on CDS would be the opposite. The result is broadly consistent with the events of 2020, when rising yields during the crisis raised the question of whether the US government bonds are a 'safe' asset (He and Krishnamurthy, 2020).

Figure 3. EME CDS in ARDL model with global financial factors

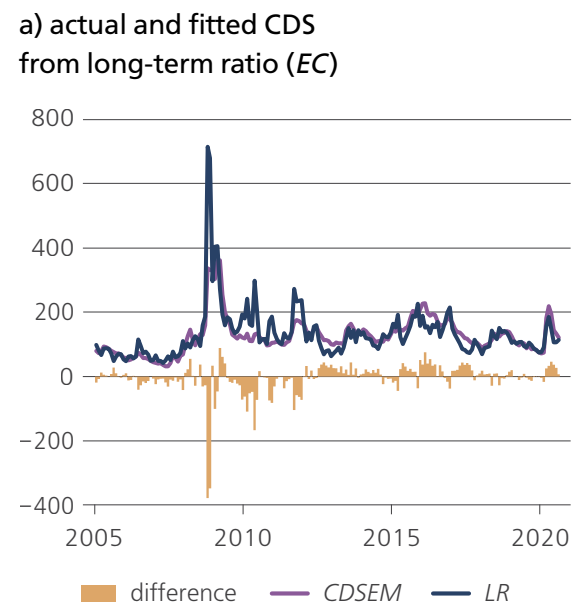

Source: author's calculations

\section{b) decomposition of CDS, $\%$ of cumulative total}

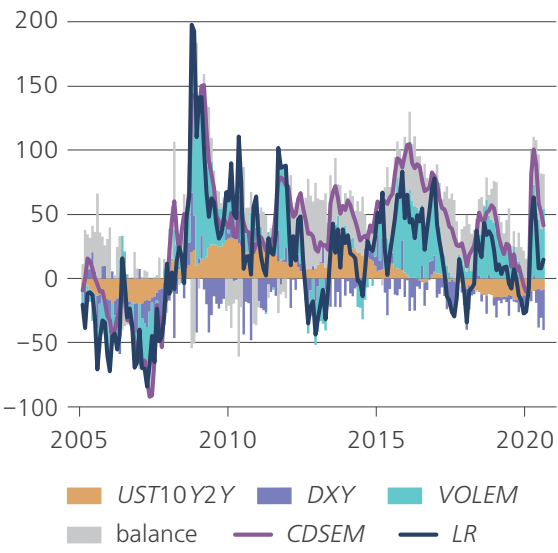

Table 3. Long-term relationship $(L R)$ from ARDL model for EME CDS

\begin{tabular}{lllll} 
Variable & Coefficient & Standard error & t-statistics & p-value \\
\hline$U S T 10 Y 2 Y_{t}$ & 0.17 & 0.07 & 2.66 & 0.01 \\
\hline VOLEM $_{t}$ & 1.39 & 0.24 & 5.89 & 0.00 \\
\hline$\Delta D X Y_{t}$ & 8.91 & 3.82 & 2.34 & 0.02 \\
\hline$c$ & 1.39 & 0.52 & 2.66 & 0.00 \\
\hline
\end{tabular}

Specification: $U S T 10 Y 2 Y_{t}=0.17 U S T 10 Y 2 Y_{t}+1.39 V O L E M_{t}+8.91 \Delta D X Y_{t}+1.39+v_{t}^{C D S}$.

Source: author's calculations

Table 4. Short-term relationship from ARDL model for EME CDS

\begin{tabular}{lllll} 
Variable & Coefficient & Standard error & t-statistics & p-value \\
\hline$\Delta U S T 10 Y 2 Y_{t}$ & 0.15 & 0.05 & 3.09 & 0.00 \\
\hline$\Delta$ VOLEM & 0.92 & 0.07 & 13.86 & 0.00 \\
\hline$E C_{t-1}$ & -0.12 & 0.03 & -4.67 & 0.00 \\
\hline
\end{tabular}

Specification: $\triangle C D S E M_{t}=-0.15 \Delta U S T 10 Y 2 Y_{t}+0.92 \Delta V O L E M_{t}-0.12 E C_{t-1}+u_{t}^{C D S}$.

Source: author's calculations 


\section{Conclusion}

Sovereign risk has a significant impact on a country's economy and financial markets, so it is important to take it into account in economic analysis and understand what determines it. There are several commonly used measures of sovereign risk: credit ratings, government bond yield spreads, and CDS. CDS are the most accurate and convenient measure for analysis. Among the determinants of sovereign CDS, the literature distinguishes local, country-specific factors (indicators of sovereign solvency, the stability of the banking sector, political stability, and institutional quality) and global factors that affect the sovereign CDS of groups of countries (due to changes in investor risk tolerance and the spread of risks across countries).

The paper provides an empirical analysis of the determinants of Russian CDS. Based on the existing literature, factors that could potentially affect Russia's sovereign risk were selected. From these factors, those that best predict CDS outside the training sample were selected. Local factors specific to Russia included the implied volatility of the rouble, an increase in which leads to an increase in CDS, and the size of foreign exchange reserves relative to GDP, the accumulation of which reduces sovereign risk. The significant impact of implied volatility on the exchange rate can be explained by the fact that, first, an increase in volatility leads to an increase in the volatility of state assets and affects the state's ability to meet its obligations, in accordance with Merton's theoretical model, and second, exchange rate volatility is formulated in the financial market by the actions of market participants and reflects their expectations regarding the future economic situation in the country, among other things. Higher foreign currency reserves, in turn, mean more state assets that can be used to repay external debt. Maintaining stability in the foreign exchange market under a floating exchange rate regime, as well as keeping foreign exchange reserves high, could help contain sovereign risks when external negative shocks occur, as they did in 2020. The proxy for global factors in the model was the average CDS spread of the other EMEs. For this index, a model was also built to determine which global factors affect the risks to EMEs. These factors, according to the analysis, are the volatility of the EME currencies, the slope of the US government bond yield curve, and the increments of the dollar index. The growth of all three factors is accompanied by a rise in CDS. The significant impact of the slope of the US government bond yield curve may reflect the impact of the US economic situation and monetary policy on EMEs and their risks, or the impact of events that simultaneously affect both US and non-US economies (such as the coronavirus pandemic). The negative impact of a rising dollar index on the EME CDS is consistent with the assumption that when the dollar strengthens, the cost of borrowing for EMEs increases meaningfully; on the other hand, dollar assets are often seen as 'safe' investments in times of crisis, so a stronger dollar could be a consequence of a general decline in risk demand, 
which also affects the EME CDS. The factor of risk demand is also reflected in currency volatility.

The method used in the paper has some drawbacks. First, the volatility of the rouble exchange rate and the volatility of the EME currencies included in the models largely play the role of proxy for various shocks, including the foreign policy shocks. Therefore, in further research it would be interesting to distinguish these as separate factors. Second, the simple ARDL model does not take into account possible structural shifts or changes in the model parameters over time. So, if a factor is not included in the model based on the variable selection algorithm, this does not mean that it has no effect on CDS - it may be that its effect simply cannot be estimated accurately enough. Also, some variables may have too little variation in the sample under consideration. For example, Russia's external debt is relatively low, and small changes in it may not have a significant impact on sovereign risk. Therefore, future studies should consider more sophisticated models, as well as the use of a larger sample to evaluate the model, which will provide an opportunity to construct a more reliable cross-validation scheme.

\section{Appendices are available at \\ http://rjmf.econs.online/en; \\ doi.org/10.31477/rjmf.202104.74}

\section{References}

Aktug, R. E. (2014). A Critique of the Contingent Claims Approach to Sovereign Risk Analysis. Emerging Markets Finance and Trade, 50(sup1), pp. 294-308.

Aldasoro, I. and Ehlers, T. (2018). The Credit Default Swap Market: What a Difference a Decade Makes. BIS Quarterly Review, June, pp. 1-14.

Ammer, J. and Cai, F. (2011). Sovereign CDS and Bond Pricing Dynamics in Emerging Markets: Does the Cheapest-to-Deliver Option Matter? Journal of International Financial Markets, Institutions and Money, 21(3), pp. 369-387.

Amstad, M., Packer, F. and Shek, J. (2020). Does Sovereign Risk in Local and Foreign Currency Differ? Journal of International Money and Finance, 101, 102099.

Arghyrou, M. G. and Kontonikas, A. (2012). The EMU Sovereign-Debt Crisis: Fundamentals, Expectations and Contagion. Journal of International Financial Markets, Institutions and Money, 22(4), pp. 658-677.

Augustin, P. (2018). The Term Structure of CDS Spreads and Sovereign Credit Risk. Journal of Monetary Economics, 96, pp. 53-76.

Augustin, P. and Tédongap, R. (2016). Real Economic Shocks and Sovereign Credit Risk. Journal of Financial and Quantitative Analysis, 51(2), pp. 541-587.

Augustin, P., Boustanifar, H., Breckenfelder, J. and Schnitzler, J. (2018). Sovereign to Corporate Risk Spillovers. Journal of Money, Credit and Banking, 50(5), pp. 857-891.

Augustin, P., Subrahmanyam, M. G., Tang, D. Y. and Wang, S. Q. (2014). Credit Default Swaps: A Survey. Foundations and Trends in Finance, 9(1-2), pp. 1-196. 
Baek, I.-M., Bandopadhyaya, A. and Du, C. (2005). Determinants of Market-Assessed Sovereign Risk: Economic Fundamentals or Market Risk Appetite? Journal of International Money and Finance, 24(4), pp. 533-548.

Bai, J., Julliard, C. and Yuan, K. (2012). Eurozone Sovereign Bond Crisis: Liquidity or Fundamental Contagion. Federal Reserve Bank of New York Working Paper.

Balima, W. H., Combes, J.-L. and Minea, A. (2017). Sovereign Debt Risk in Emerging Market Economies: Does Inflation Targeting Adoption Make any Difference? Journal of International Money and Finance, 70, pp. 360-377.

Beck, R. (2001). Do Country Fundamentals Explain Emerging Market Bond Spreads? CFS Working Paper, N 2.

Benzoni, L., Collin-Dufresne, P., Goldstein, R. S. and Helwege, J. (2015). Modeling Credit Contagion via the Updating of Fragile Beliefs. Review of Financial Studies, 28(7), pp. 1960-2008. https://doi.org/10.1093/rfs/hhv018

Bocola, L. (2016). The Pass-Through of Sovereign Risk. Journal of Political Economy, 124(4), pp. 879-926.

Borio, C. E. and Packer, F. (2004). Assessing New Perspectives on Country Risk. BIS Quarterly Review, December, pp. 47-65.

Breckenfelder, J. (2018). How is a Firm's Credit Risk Affected by Sovereign Risk? European Central Bank Research Bulletin, N 53.

Caceres, C., Guzzo, V. and Segoviano Basurto, M. A. (2010). Sovereign Spreads: Global Risk Aversion, Contagion or Fundamentals? IMF Working Paper, N 120.

Carr, P. and Wu, L. (2007). Theory and Evidence on the Dynamic Interactions between Sovereign Credit Default Swaps and Currency Options. Journal of Banking and Finance, 31(8), pp. 2383-2403. https://doi.org/10.1016/j.jbankfin.2006.09.008

Chuffart, T. and Hooper, E. (2019). An Investigation of Oil Prices Impact on Sovereign Credit Default Swaps in Russia and Venezuela. Energy Economics, 80, pp. 904-916.

Coudert, V. and Gex, M. (2013). The Interactions between the Credit Default Swap and the Bond Markets in Financial Turmoil. Review of International Economics, 21(3), pp. 492-505. https://doi.org/10.1111/roie.12050

Culp, C. L., van der Merwe, A., Stärkle, B. J. (2016). Single-Name Credit Default Swaps: Review of Empirical Academic Literature. ISDA.

De Santis, R. A. (2012). The Euro Area Sovereign Debt Crisis: Safe Haven, Credit Rating Agencies and the Spread of the Fever from Greece, Ireland and Portugal. European Central Bank Working Paper Series, N 1419.

Della Corte, P., Sarno, L., Schmeling, M. and Wagner, C. (2021). Exchange Rates and Sovereign Risk. CEPR Discussion Paper, N DP16058.

Dooley, M. and Hutchison, M. (2009). Transmission of the US Subprime Crisis to Emerging Markets: Evidence on the Decoupling-Recoupling Hypothesis. Journal of International Money and Finance, 28(8), pp. 1331-1349.

Du, W. and Schreger, J. (2016). Local Currency Sovereign Risk. Journal of Finance, 71(3), pp. 1027-1070. https://doi.org/10.1111/jofi.12389

Duffie, D. (1999). Credit Swap Valuation. Financial Analysts Journal, 55(1), pp. 73-87.

Edwards, S. (1983). LDC's Foreign Borrowing and Default Risk: An Empirical Investigation. NBER Working Paper, N 1172. https://doi.org/10.3386/w1172 
Edwards, S. (1986). The Pricing of Bonds and Bank Loans in International Markets: An Empirical Analysis of Developing Countries' Foreign Borrowing. European Economic Review, 30(3), pp. 565-589. https://doi.org/10.1016/0014-2921(86)90009-7

Eichler, S. (2014). The Political Determinants of Sovereign Bond Yield Spreads. Journal of International Money and Finance, 46, pp. 82-103.

Ertugrul, H. M. and Ozturk, H. (2013). The Drivers of Credit Default Swap Prices: Evidence from Selected Emerging Market Countries. Emerging Markets Finance and Trade, 49(sup5), pp. 228-249. https://doi.org/10.2753/REE1540-496X4905S514

Gray, D. and Malone, S. (2008). Macrofinancial Risk Analysis. John Wiley \& Sons.

Gray, D. F., Merton, R. C. and Bodie, Z. (2007). Contingent Claims Approach to Measuring and Managing Sovereign Credit Risk. Journal of Investment Management, 5(4), pp. 5-28.

Gyntelberg, J., Hördahl, P., Ters, K. and Urban, J. (2013). Intraday Dynamics of Euro Area Sovereign CDS and Bonds. BIS Working Papers, N 423.

Hassan, M. K., Ngene, G. M. and Yu, J.-S. (2015). Credit Default Swaps and Sovereign Debt Markets. Economic Systems, 39(2), pp. 240-252.

He, Z. and Krishnamurthy, A. (2020). Are US Treasury Bonds Still a Safe Haven? NBER Reporter, 3, pp. 20-24.

Ismailescu, I. and Kazemi, H. (2010). The Reaction of Emerging Market Credit Default Swap Spreads to Sovereign Credit Rating Changes. Journal of Banking and Finance, 34(12), pp. 2861-2873. https://doi.org/10.1016/j.jbankfin.2010.05.014

Kallestrup, R., Lando, D. and Murgoci, A. (2016). Financial Sector Linkages and the Dynamics of Bank and Sovereign Credit Spreads. Journal of Empirical Finance, 38, pp. 374-393. https://doi.org/10.1016/j.jempfin.2016.01.004

Kocsis, Z. and Monostori, Z. (2016). The Role of Country-Specific Fundamentals in Sovereign CDS Spreads: Eastern European Experiences. Emerging Markets Review, 27, pp. 140-168. https://doi.org/10.1016/j.ememar.2016.05.003

Kose, M. A., Nagle, P., Ohnsorge, F. and Sugawara, N. (2021). Global Waves of Debt: Causes and Consequences. Washington, DC: World Bank.

Laeven, L. and Valencia, F. (2013). Systemic Banking Crises Database. IMF Economic Review, 61(2), pp. 225-270. https://doi.org/10.1057/imfer.2013.12

Li, H., Li, T. and Yang, X. (2014). A rating-based sovereign credit risk model: Theory and evidence [Paper Presentation]. European Financial Management Association Annual Meetings 2014: Rome, Italy.

Li, N. (2009). The Price Discovery Process in Credit Derivative Market: Evidence from Sovereign CDS Market. American Journal of Finance and Accounting, 1(4), pp. 393-407.

Li, N. and Huang, A. Y. (2011). Price Discovery between Sovereign Credit Default Swaps and Bond Yield Spreads of Emerging Markets. Journal of Emerging Market Finance, 10(2), pp. 197-225. https://doi.org/10.1177/097265271101000203

Longstaff, F. A., Mithal, S. and Neis, E. (2005). Corporate Yield Spreads: Default Risk or Liquidity? New Evidence from the Credit Default Swap Market. Journal of Finance, 60(5), pp. 2213-2253. https://doi.org/10.1111/j.1540-6261.2005.00797.x

Longstaff, F. A., Pan, J., Pedersen, L. H. and Singleton, K. J. (2011). How Sovereign Is Sovereign Credit Risk? American Economic Journal: Macroeconomics, 3(2), pp. 75-103. 
Pan, J. and Singleton, K. J. (2008). Default and Recovery Implicit in the Term Structure of Sovereign CDS Spreads. Journal of Finance, 63(5), pp. 2345-2384.

Panetta, F., Correa, R., Davies, M., Di Cesare, A., Marques, J.-M., Nadal de Simone, F., Signoretti, F., Vespro, C., Vildo, S., Wieland, M. and Zaghini, A. (2011). The Impact of Sovereign Credit Risk on Bank Funding Conditions. Bank for International Settlements, Committee on the Global Financial System (CGFS) Papers, N 43

Pesaran, M. H. and Shin, Y. (1999). An Autoregressive Distributed-Lag Modelling Approach to Cointegration Analysis. In: S. Strøm, ed. Econometrics and Economic Theory in the 20th Century: The Ragnar Frisch Centennial Symposium. Cambridge: Cambridge University Press, pp. 371-413. https://doi.org/10.1017/ccol521633230.011

Plank, T. (2010). Do Macro-economic Fundamentals Price Emerging Market Sovereign CDS Spreads? Working Papers from University of Pennsylvania, Weiss Center for International Financial Research. https://doi.org/10.2139/ssrn.1765352

Raja, Z. A., Procasky, W. J. and Oyotode-Adebile, R. (2020). The Relative Role of Sovereign CDS and Bond Markets in Efficiently Pricing Emerging Market Sovereign Credit Risk. Journal of Emerging Market Finance, 19(3), pp. 296-325.

Reinhart, C. M. and Rogoff, K. S. (2008). This Time is Different: A Panoramic View of Eight Centuries of Financial Crises. NBER Working Paper, N13882.

Reinhart, C. M. and Rogoff, K. S. (2011). The Forgotten History of Domestic Debt. Economic Journal, 121(552), pp. 319-350.

Remolona, E. M., Scatigna, M. and Wu, E. (2008). The Dynamic Pricing of Sovereign Risk in Emerging Markets: Fundamentals and Risk Aversion. The Journal of Fixed Income, 17(4), pp. 57-71. https://doi.org/10.3905/jfi.2008.705542

Rodríguez, I. M., Dandapani, K. and Lawrence, E. R. (2019). Measuring Sovereign Risk: Are CDS Spreads Better than Sovereign Credit Ratings? Financial Management, 48(1), pp. 229-256. https://doi.org/10.1111/fima.12223

Sgherri, S. and Zoli, E. (2011). Euro Area Sovereign Risk During the Crisis. In: R. W. Kolb, ed. Sovereign Debt. John Wiley \& Sons, pp. 415-424.

Stolbov, M. (2017). Determinants of Sovereign Credit Risk: The Case of Russia. Post-Communist Economies, 29(1), pp. 51-70.

Wang, P. and Moore, T. (2012). The Integration of the Credit Default Swap Markets During the US Subprime Crisis: Dynamic Correlation Analysis. Journal of International Financial Markets, Institutions and Money, 22(1), pp. 1-15.

White, L. J. (2010). Markets: The Credit Rating Agencies. Journal of Economic Perspectives, 24(2), pp. 211-26. https://doi.org/10.1257/jep.24.2.211

Xiao, Y., Yan, H. and Zhang, J. (2019). Global Perspective or Local Knowledge: The MacroInformation in the Sovereign CDS Market. DePaul University, Dreihaus College of Business Publications. 